\title{
Isolation and characterization of plant growth promoting Burkholderia spp
}

M. SIVAJI*, R. VINOTH ${ }^{1}$, P. TAMILKUMAR ${ }^{2}$, S.SURESH KUMAR, A.CHANDRASEKAR AND M. SYAMALA $^{3}$

Department of Plant Biotechnology, Tamil Nadu Agricultural University, COIMBATORE (T.N.) INDIA ${ }^{1}$ Centre for Plant Breeding and Genetics, Tamil Nadu Agricultural University, COIMBATORE (T.N.) INDIA

${ }^{2}$ Department of Seed Science and Technology, Tamil Nadu Agricultural University, COIMBATORE (T.N.) INDIA

${ }^{3}$ Department of Plant Pathology, Tamil Nadu Agricultural University, COIMBATORE (T.N.) INDIA

\section{ARITCLE INFO}

Received : 29.01 .2016

Revised : 02.03 .2016

Accepted : 10.03 .2016

KEY WORDS :

Plant growth promoting rhizobacteria, Burkholderia sp., Polymerase chain reaction
*Corresponding author:

Email: sivajibt@gmail.com

\begin{abstract}
In this study, a total of eight Burkholderia isolates obtained from rhizosphere soil of maize, cotton, rice, sugarcane, groundnut and soybean and tested for the $\mathrm{N}$ fixation, phosphate solubilisation and antagonistic activity against Rhizoctonia solani. All the eight isolates produced the band for the nifH gene in the polymerase chain reaction confirmed the presence of nifH gene. Among the 8 isolates, RMS1 produced clear halo zone around $7 \mathrm{~mm}$ on surface of HAP medium. CMS1, RMS1 and SMS1 are inhibited the growth of Rhizoctonia solani for 43, 40 and 35 per cent, respectively. An isolate RMS1 possessed all the three plant growth promoting traits viz., higher phosphate solubilizing ability, antagonistic activity and presence of nifH gene selected for molecular characterization with amplifying and sequencing of $1.46 \mathrm{~kb} 16 \mathrm{~S}$ rRNA gene. Based on the BLASTn homology it was found that $16 \mathrm{~S}$ rRNA sequence of isolate RMS1 having 93 per cent identity with showed 97 per cent homology with Burkholderia thailandensis.

How to view point the article : Sivaji, M., Vinoth, R., Tamilkumar, P., Kumar, S. Suresh, Chandrasekar, A. and Syamala, M. (2016). Isolation and characterization of plant growth promoting Burkholderia spp. Internat. J. Plant Protec., 9(1) : 223-229.
\end{abstract}

